\title{
Cultural Significations of Heterotopian Spaces of Nature
}

\section{Werner Bigell}

University of Matanzas (Cuba)

\begin{abstract}
Michel Foucault's concept of heterotopia provides a useful tool for understanding the social function of natural spaces. Heterotopian spaces exist inside a social order but are characterized by a relative lack of control and a different set of rules and expectations. This article proposes a typology of the cultural responses to heterotopian natural spaces: the modes of edification, health, deviance, and crisis. Edification means that personal growth or spiritual improvement can be obtained through exposure to natural spaces; in a commoditized form edification also fuels social distinction. The mode of health refers to physical health, but also, in the wider sense of the etymological roots of the word, to wholeness and the holy; examples are the German tradition of nudism and the Norwegian tradition of friluftsliv (outdoor life). Deviation can be seen in political resistance (as in guerilla warfare) and evasion from the law; in a commoditized touristic form it means release from everyday life. The mode of crisis, a temporary state of unsettlement, can be found in the attempt to find repose in nature, to live through an existential crisis, or, in a commoditized form, in the calculated danger of adventure. The typology is useful for distinguishing between seemingly similar forms of nature use and to identify parallels between apparently different forms.
\end{abstract}

Keywords: Heterotopia - Foucault - Edward Abbey - nudism - friluftsliv tourism-edification - health - deviation - crisis

In The History of Sexuality Michel Foucault describes how sexuality disappears from the public view in the $17^{\text {th }}$ century only to reappear in new discursive spaces such as science and medicine. But not all new spaces are discursive: in its licit form, sexuality is relegated to the bedrooms, and in it illicit forms into spaces such as brothels and mental hospitals, which became "places of tolerance" $(1976,4)$. Here Foucault hints at the interrelatedness between discursive practices and real spaces, and in a later text ("Of Other Spaces") he elaborates how a culture creates spaces that exist within a cultural order 
but that are nonetheless marked by rules and expectations different from the cultural center. In contrast to utopias, heterotopias are real spaces, "places that do exist and that are formed in the very founding of society - which are something like counter-sites, a kind of effectively enacted utopia in which the real sites, all the other sites that can be found within the culture, are simultaneously represented, contested, and inverted" (1986, 24). The usefulness of Foucault's idea of heterotopia lies in the fact that the term allows us to go beyond the nature-culture dichotomy while retaining the distinction between discursive and spatial orders, i.e. between language and real space.

Even though the imaginative response to physical spaces is open to a great variety of signification, clear cultural patterns are apparent. Thus Foucault speaks of heterotopias of "crisis" and "deviance," to which I propose to add two additional categories: health and edification. The cultural significance of natural spaces can be analyzed, then, through four main categories: deviance, crisis, health, and edification. ${ }^{1}$ The aim of proposing these categories is to analyze accounts of nature experiences, to distinguish between apparently similar experiences, and to find parallels between seemingly different activities. In this article I propose a typology of the social function of natural heterotopian spaces. These spaces cannot merely be seen as the location for escape from the complexities of society; to the contrary, these spaces are necessary elements for the openness of a culture.

The work of the American nature writer Edward Abbey may be taken as a good illustration of the idea of heterotopia. His depiction and reflection on the wilderness of the American Southwest shows how real natural spaces manage to exist within a cultural order while being perceived to be outside of it: "The boundary around a wilderness area may well be an artificial, self-imposed sophisticated construction, but once inside that line, you discover the artificiality beginning to drop away; and the deeper you go, the more interesting things get - sometimes fatally interesting" (1991a, 230). Abbey suggests that the experience of a natural space is not predetermined by its administrative status. Instead it is the relative openness for individual signification that defines a heterotopian space. A space where experience is thoroughly predetermined, such as Disneyland, has lost its heterotopian quality. Although both cultural and natural spaces can function as heterotopias, natural spaces are 
predestined heterotopias because of their distance from cultural centers, scarcity of human population and lack of infrastructure - all of which contribute to a lessening of social control. While real in their physicality and 'naturalness' (natural in the sense of a minimal human and technological presence), heterotopias are also cultural spaces. This quality of participating in both nature and culture is a means of overcoming the nature-culture dualism that often mars environmental studies.

\section{Edification}

The core of the experience of edification is a search for individual or collective identity based on a belief in human progress. Nina Witoszek describes a common perception of nature in the $18^{\text {th }}$ century as an experience of edification: "nature was a place for meditation, a source of joy and pride, a teacher, a bridge to the divine" (1998, 29, my translation). In Peter Matthiesen's The Snow Leopard, nature is a teacher, and meditation affirms the self:

The search may begin with a restless feeling, as if one were being watched. One turns in all directions and sees nothing. Yet, one senses that there is a source for this deep restlessness: and the path that leads where there is not a path to a strange place, but the path home. ("But you are home," cries the Witch of the North. "All you have to do is wake up!"') The journey is hard, for the secret place where we always have been overgrown with thickets of "ideas," of fears and defenses, prejudices and repressions. The holy grail is what Zen Buddhists call our own "true nature"; each man is his own savior after all. (Matthiesen quoted in Chambers, 73)

Matthiesen here describes a process of individual edification and growth through exposure to a natural space. As the metaphor of edification suggests, it is an identity-building process. Whereas the edified identity in the case of Matthiesen is individual, it can also be a group identity, such as a national identity. In her book Norske Naturmytologier, Witoszek argues that nature forms the foundation of Norwegian national identity. A political sense of group edification underlies the frequently organized mountain hikes retracing the movements of the Cuban revolutionary war, organized by the Cuban Young Communist League (UJC). ${ }^{2}$ 
Edification often exists in a commoditized variant that does not focus on individual or group development but rather on social distinction, a distinction that Abbey sees at the basis of Matthiesen's edification: "Good writing, but - there's something ludicrous and pathetic in the spectacle of these rich Americans going all the way to Nepal, trekking through the Himalaya, followed by a string of porters bearing the white man's burden, spending thousands of dollars, in order to - 'find themselves'!" (1994, 282-83). A common element for a commoditized form of edification is the search for authenticity, the experience of which can be transformed into conspicuous consumption. Alex Garland's novel The Beach is an ironic rendering of the fact that backpackers in search for the ultimate authentic unspoiled beach are motivated by a fear of the masses and, at the same time, form the forefront of mass tourism.

The theme of commoditized edification is further illustrated in the 'rites of passage' narrative. In his satirical novel Are you Experienced?, William Sutcliffe mocks the idea of spiritual improvement that underlies the theme of "finding oneself" in India. The protagonist describes why his friends spent the year between school and university on "some journey to a poverty-stricken flea pit half way up a malaria-infested mountain on the other side of the planet." Apparently, "[t]here was the general belief that a long and unpleasant holiday was of crucial importance to one's development as a human being" (1997, 32). The aim of "roughing it" is edification, a process that is rewarded by social distinction, as Sutcliffe character Dave notes after his trip to India: "As a new person, the time was right to clear the way for new friends. That was the whole point of university. I would be able to begin again as the new me - not as Dave the mediocre North London schoolboy, not as Dave the sexual failure, but as Dave the traveler" $(1997,235)$. Although the narrator continually mocks commoditized forms of edification in a search for authenticity, by the end of the novel he accepts them for himself and leaves it to the reader to draw the line between true and commoditized edification.

The lines between true individual or group edification on the one hand and commoditized edification with the aim of social distinction are not easy to draw. Whereas Matthiesen would certainly see his nature experience as individually edifying, Abbey identifies an element of commoditization in it.

actions the revolutionaries come close to Cuba's highest mountain, the Pico Turquino, Che decides to climb it, not so much out of military necessity but for reasons of edification. This climb is today re-enacted by the state youth organization, promoting a combination of revolutionary and national edification. As in Norway, the mountains here symbolize independence and national unity. 
The same goes for the ironic and evasive narrator of Are You Experienced?, who leaves it to the reader to draw this line. Whereas in terms of individual experience the distinction between true and commoditized edification is a matter of degree and perspective, the case is clearer when one looks at factors such as administration and cultural perceptions of tourism. It has become a cliché that an edifying experience of natural spaces is threatened by mass tourism, and that tourists destroy what they love most; this cliché is the reason for the distinction between the terms "tourist" and "traveler." In his essay "Industrial Tourism and the National Parks" (1992), Edward Abbey notes that environmental protection is often understood to be rooted in a fear of the masses. He argues against this view and claims that it is not the number of visitors that destroy edifying experience, but rather that commoditization, in particular motorized traffic, destroys the heterotopian quality of the National Parks. Abbey here argues against the elitist connotations of the experience of edification.

\section{Health}

The etymology of the word "health" links it to the concepts "wholeness" and "holy." Health in a narrow sense refers to physical wellbeing, whereas the term in a wider sense refers to harmony between body and social or natural environment. Uses of natural spaces that are motivated by health include the German tradition of nudism and the Norwegian tradition of open air life ( $\mathrm{rr}^{-}$luftsliv). The experience of physical health in natural spaces is a feature of German and Scandinavian cultures. In an American context nudity is often linked to deviance and examples here may be the display of nudity of the 1960 's countercultural movement (a remnant of which survives in the Burning Man Festival in the Nevada desert), the mass nude installations organized by the photographer Spencer Tunick, or Larry Clark's film Ken Park where adolescent nudity is contrasted to a corrupt adult world. One also finds deviance in the history of European public nudity. Whereas nude bathing in lakes and rivers has always been part of rural culture, the Romans brought bathhouses to Germany, which continued to exist through the Middle Ages. These bathhouses had various functions, from being social meeting places, to flirting arenas, to places of prostitution (König 1999, 46). Due to a changed moral climate these bathhouses ceased to exist in the $16^{\text {th }}$ century. 
When the practice of nude and public bathing was advocated once more in the mid-19 $9^{\text {th }}$ century Germany, there was a much stricter moral framework, and a revival of the medieval bathhouses with their cultivation of deviance would have been unthinkable. Why did it come back at all? Nudism was an element of naturism and the German movement of Lebensreform ("life reform"), which, inspired by romantic thought, sought proximity to nature. Clothes were seen as impeding contact with nature and as unduly restraining the body. ${ }^{3}$ In order to be socially accepted or at least legally tolerated, German nudists had to distinguish themselves from both the bathhouse tradition and from the perceived 'decadence' of bohemians who use both nudity and eroticism in their protest against bourgeois norms and mores (Schneider 1999, 73). German nudists developed an ideology of health, disciplined the body and proclaimed an asexual nudity; gymnastics and other form of sport were popular in nudist camps, whereas sexual activity or visible arousal led to expulsion.

For the movement of Lebensreform, health was an issue larger than physical fitness; it included the "double health of individual and culture" (Schneider $1999,75)$. The body was seen more and more as a sacred temple, and spiritual life aimed at a recovery of a pre-Christian and pantheistic physicality. Natural spaces were seen as houses of God outside the body, and real natural spaces were converted to spaces of individual and collective search of health and the holy (Ulbricht 1999, 158). Whereas medieval bathhouses were located in cities, nudism was practiced in rural spaces, and was heterotopian, both in its proximity to nature and in its remoteness. Like the Lebensreform movement, in the Norwegian tradition of friluftsliv there is an extension of the concept of health to wholeness and holiness.

As in German nudism there is a romantic element in Norwegian friluftsliv. Fridtjof Nansen wants to get urban people "away from the accustomed" because "urban life is after all unnatural" (Nansen 1994, 7). Nansen expands the notion of health in his definition of friluftsliv: "There may well be a little too much emphasis on sport instead of the Sporting pastime; too many "records" and too much specialization. [...] This may well develop the body, at least part of it, but the spirit should also be included" (1994, 7). Arne Naess provides a similar definition of friluftsliv: "Norwegians walk, run, creep into

3. Also walls were seen as essentially unhealthy, and around the turn of the $20^{\text {th }}$ century hospitals in Germany were built with large terraces and extensive parks or even in bungalow style in order to provide as much of Licht und Luft ("light and air") as possible. Modern hospital buildings are more compact, due to concerns about hygiene and short distances, and the change of architectural styles can still be seen, for example in the University Hospital of Düsseldorf, Germany. 
nature to get rid of whatever represses them and contaminates the air, not only the atmosphere. [...] [They] come back wholer [sic], surer of themselves, readier [sic] to face the problems inevitably confronting them in cities, towns, even in their old local communities" (Naess 1994, 15). Both authors stress that the experience of natural spaces is more than enhancing physical fitness; friluftsliv fosters metal health and a sense of wholeness that may well prepare for the holy. Both friluftsliv and the Lebensreform movement have stressed the importance of health both in terms of bodily discipline and ecological and social health. An example for a health-promoting use of natural spaces is the Norwegian documentary film For Harde Livet (Endresen 2005) that shows drug addicts from Oslo living on a remote farm and engaging in strenuous outdoor activities to overcome their drug dependence and to regain physical, mental, and social health.

\section{Deviance}

In Jimi Hendrix's version of the song Hey Joe (1967), the protagonist has killed his wife and is asked where he is going to run:
I'm going way down south /
Way down to Mexico way
$[\ldots]$ /
Way down where I can be free /
Ain't no one gonna find me. ${ }^{4}$

Hendrix recycles the myth of Mexico as the last frontier, a place wilder and less controlled than the Wild West, a place to hide. Whereas finding a place to hide (Huck Finn wanted to "light out for the Territory" after his rafting escape had ended) has been a staple theme in North American literature, in Latin America natural spaces are often used for another type of deviance, namely armed resistance. The Cuban revolution was only possible because natural spaces provided a safe haven for the guerilla. Already in the 1940s the young student Fidel Castro explored the Pinares de Mayari in Eastern Cuba and understood that nature at this place could become "an ally in a battle, be con- 
verted into a formidable force, and that the forest could be a combat weapon" (Jesús 2004, 21, my translation).

The film Brokeback Mountain (2005) depicts a related experience of deviance. Whereas homosexuality is dangerous in the cowboy culture of the American West, the characters escape that culture and live temporarily "out there in the middle of nowhere" according to their sexual inclination. Edward Abbey describes a similar heterotopia of sexual deviance:

Great Bend Drive-In Movie Theater: an imposing edifice of six Corinthian columns with bell-shaped capitals feigning support of a towering façade of painted aluminum. Black letters on the white marquee announce the current attraction: FOR SALE 12 ACRES. Death of another passion pit. No more necking, no more heavy petting in the cockpit of Dad's LTD (1991, 344, emphasis Abbey's).

Abbey laments the end of a heterotopia where deviance in the form of sexual activity of unmarried couples was possible. In Aldous Huxley's Brave New World there are two examples of heterotopian spaces; one is the island to which people who show individual thought are deported, and the other is the desert of the Indian reservation, where the old ways such as natural childbearing survive. Island and desert are well suited to function as heterotopias because of they present physical barriers to the spaces of the cultural center. Whereas the above mentioned examples contain an element of cultural resistance (whether tolerated by society or not), there are commoditized forms of deviance that do not imply resistance but are nevertheless enacted in distinct and removed spaces as to not disturb social order.

A form of ritualized and commoditized deviant behavior is found in the idleness and release of spaces dedicated to tourism. Foucault describes "those Polynesian villages that offer a compact three weeks of primitive and eternal nudity to the inhabitants of the cities" $(1986,26)$. The nudity experienced in such a vacation village is not motivated by health but is a ritualized form of deviance. Many types of behavior that are undesirable, regulated, or prohibited in the social center are permitted and even expected during a vacation in a heterotopian space. Such behavior includes idleness, nudity, promiscuity, drug use, and drinking, illustrated for example by the American tradition of spring break. The behavioral patterns during such vacations are not deviant in the sense that they oppose the social order but rather are ritualized and commoditized forms of deviance.

The social function of ritual deviance is to provide a safety valve through release. Even outdoor activities such as hiking can be dominated by a sense of release: 
From the edge we look down almost directly on the river and our bright little orange skiffs lined up like toys in the sand. We can see Kevin Briggs lying there, sleeping another one off. Perhaps we should drop a few boulders down his way, wake him up, make sure he is all right? That suggestion is tabled but the urge to violence and destruction on the part of some cannot be wholly suppressed. One member of our party, followed soon by two others, leads a scramble across loose talus to a better promontory upriver. There they sweat and grunt for a while until they succeed in dislodging a halfton block of limestone; they nudge it off the brink, it falls revolving lazily in space, and explodes on impact far below. (Abbey 1991, 138-39)

Abbey's attitude may strike a reader familiar with nature writing as irreverent, arrogant, and destructive. Such a criticism, however, misses the point that the mode of Abbey's experience is release, a ritualized form of deviance, not edification or health.

\section{Crisis}

The term crisis denotes a turning point in a process of change or a temporary state of unsettlement and can have both negative and positive connotations. Crises are often linked to specific sites, and Foucault sees psychiatric hospitals as heterotopias for "individuals who are, in relation to society [...] in a state of crisis: adolescents, menstruating women, pregnant women, the elderly, etc." An example for a heterotopia of crisis is the honeymoon trip which Foucault explains thus: "The young woman's deflowering could take place 'nowhere' and, at the moment of its occurrence the train or honeymoon hotel was indeed the place of this nowhere" $(1996,24)$. The sociologist John Urry makes a similar observation:

Going on honeymoon to Niagara did indeed involve a pilgrimage, stepping out into an experience of liminality in which the codes of normal social experience were reversed. In particular honeymooners found themselves historically in the ideal liminal zone where the strict social conventions of bourgeois families were relaxed under the exigencies of travel and of relative anonymity and freedom from collective scrutiny. $(2002,11)$

The idea of "liminality," of being "neither here nor there," is another expression for the actual heterotopian spaces that are experienced as 'nowhere.' Nowhere is the ground, the foundation for crisis. Another example for this 
"nowhere" is the French Foreign Legion, which helps young men to disappear from their world.

Crises can be both physical and existential, and an example is found in Jack London's story "How to Build a Fire," where the nameless protagonist is reduced to an animal-like state (without possessing the instincts of an animal) in a survival situation. Other existential crises combine the physical with the spiritual and lead to a reassessment of life; examples for this form of crisis in a heterotopian space are Jesus' venture into the desert or Mary Rowlandson's captivity narrative. In both these narratives natural spaces facilitate the unsettling and re-settling of the character. A modern version of an existential crisis enacted in a both real and metaphorical desert is Paul Bowles' The Sheltering Sky:

Before her eyes was the violent blue sky - nothing else. For an endless moment she looked into it. Like a great overpowering sound it destroyed everything in her mind, paralyzed her. Someone once had said to her that the sky hides the night behind it, shelters the person beneath from the horror that lies above. $(1990,328)$

The desert is so overpowering that the only end points of the existential crisis are death and madness. Whereas Bowles' depiction marks one extreme of an existential crisis, there are commoditized forms of crisis that are neither lethal nor maddening.

In her short story “I Was a Captain in Colonel Bob's Army," Pam Houston recalls how she experienced the danger and excitement of an organized trip to "the West" as a child and only much later learns that the supposed wilderness was an unkempt section of the city park. Today this experience is impossible even though the park as such had not been changed. However because of the construction of a new skyscraper there "wasn't a place in town from which you couldn't see that building, not even down in the canyon, not even under the thick canopy of trees in Apache Gulch" (1999, 122-123). The skyscraper had not destroyed the overgrown areas of the city park, but it had destroyed the park's potential to serve as a heterotopia for crisis in the form of adventure. An important element of crisis is danger since it signals that the forces of unsettling are real. Danger can be uncontrolled as in an existential crisis or controlled as in the ritualized crisis of adventure. Danger signals the heterotopian quality of a space because it demonstrates the relative lack of control - whether social or physical/technological: "Wilderness is and should be a place where, as in Central Park, New York City, you have a fair chance of 
being mugged and buggered by a shaggy fellow in a fur coat - one of Pooh Bear's big brothers" (Abbey 1991a, 230).

Natural spaces can function in a manner analogous to Foucault's psychiatric hospitals. Abbey describes why he goes on a solitary river trip: "I preferred this kind of solitude not out of selfishness but out of generosity; in my sullen mood I was doing my fellow humans [...] a favor by going away" $(1988,94)$. Note that the motivation for going to nature in this case is not healing but surviving a crisis. Heterotopian spaces not only provide a space for living through a crisis but can induce a temporary mental instability similar to intoxication:

[I] dreamed away days on the shore of the pool under the waterfall, wandered naked as Adam under the cottonwoods, inspecting my cactus gardens. The days became wild, strange, ambiguous - a sinister element pervaded the flow of time. I lived narcotic hours in which like the Taoist Chuang-tse I worried about butterflies and who was dreaming that $[\ldots]$ I slipped into degrees of lunacy, me and the moon, and lost to a certain extent the power to distinguish between what was and was not myself: looking at my hand I would see a leaf trembling on a branch. (Abbey 1992, 200)

Whereas some crises are existential (physical or spiritual or both), others are commoditized and experienced as "adventures." For all types the experience of being unsettled defines an important cultural function.

\section{Conclusion}

I have proposed a classification of experiences in heterotopian natural spaces in order to overcome the nature-culture dichotomy that often marks environmental debates. Often it is not clear what exactly is to be protected or what is lost through a development of natural spaces. Zapffe illustrates this point: "Someone in Troms $\varnothing$ wrote: 'All too few enjoy the stunning loneliness in Ørnedalen. When the ring road comes, this will change.' He was right. Now 'all' can take the bus to Ørnedalen. But what shall they do there?' (1993, 127; my translation). Whereas development in the form of creating access for motorized traffic may or may not have an impact on the ecosystem, it will likely interfere with all forms of experience of natural spaces, edification, health, crisis, and deviation. The only form of experience that motorized access promotes is commoditized deviance in the form of release. This narrowing of the scope of experience limits the heterotopian quality of a space. 
Besides clarifying what is to be protected and why, a classification of nature experiences can distinguish between seemingly similar experiences. Mountaineering for Jon Krakauer is an experience of edification in which "[c]limbing mattered" and the "world was made real" (1996, 134). For Zapffe, on the other hand, mountaineering evokes a feeling of existential spiritual crisis: it is "not a sport" but "meaningless as life itself - therefore its magic can never die" (1993, 92, my translation). Another important distinction is that between health and deviance. Thus while nudism in heterotopian spaces is an expression of health in Germany, it is a transgressive expression in many other cultures. The same distinction must be made to understand the use of nature for outdoor activities. Whereas in some countries natural spaces are primarily used in a health-mode, in other countries outdoor activities are commoditized deviation in the form of release. A memorable example for this is Long Litt Woon's description of her first exposure to Norwegian friluftsliv (Kløvstad 1993). She is shocked by the strenuous and non-social quality of Norwegians' experience of nature until she learns that health and inner peace, not sociability and liveliness, define the experience of friluftsliv. ${ }^{5}$

The concept of heterotopia is useful for an analysis of the spatial qualities of cultural margins and centers. What makes a space at the same time marginal and important for a culture is its heterotopian quality, i.e. its relative lack of control and its openness for signification. Edification, health, crisis, and deviance are typical responses that result from an individual or collective cultural encounter with heterotopian spaces of nature. Central social spaces and heterotopian spaces coexist in a symbiotic tension, as Abbey explains: "What makes life in our cities at once still tolerable, exciting, and stimulating is the existence of an alternative option, whether exercised or not, [...] of a radically different mode of being out there, in the forests, on the lakes and rivers, in the deserts, up in the mountains" (1991a, 229). 


\section{Works Cited}

Abbey, Edward. 1988. One Life at a Time, Please. New York: Henry Holt.

- 1991. Down the River. New York: Plume.

- 1991a. The Journey Home. New York: Plume.

- 1992. Desert Solitaire. London: Robin Clark.

- 1994. Confessions of a Barbarian: Selections from the Journals of Edward Abbey, 1951 - 1989. Boston: Little Brown.

Bowles, Paul. 1990. The Sheltering Sky. New York: Vintage.

Chambers, Erve. 2000. Native Tours: The Anthropology of Travel and Tourism. Prospect Heights, Illinois: Waveland Press.

Cohen, Erik. 1979. “A Phenomenology of Tourist Experiences.” Sociology 13: 179-201.

Dahle, Børge (ed.). 1994. Nature: The True Home of Culture. Oslo: Norges Idrettshøgskole.

Endresen, Sigve (director). 2005. "For Harde Livet." DVD. Oslo: Sandrew Metronome.

Foucault, Michel. 1976. The History of Sexuality, Volume 1: An Introduction. London: Penguin.

- 1986. "Of Other Spaces.” Diacritics 16, Spring 1986: 22-27.

Grisko, Michael (ed.). 1999. Freikörperkultur und Lebenswelt: Studien zur Vor-und Frïhgeschichte der Freikörperkultur in Deutschland. Kassel: Kassel University Press.

Guevara, Ernesto Che. 1985. Pasajes de la Guerra Revolucionaria. Havana: Editorial de Ciencias Sociales.

Gullestad, Marianne. 1989. Kultur og Hverdagsliv. Oslo: Universitetsforlaget.

Houston, Pam. 1999. A Rough Guide to the Heart. London: Virago Press.

Jesús, Rafael. 2004. "Los bosques y su historia". In Se Puede Vivir en Ecopolis. Año 8, Num. 29 (Enero - Marzo 2004). La Habana: Fundación Antonio Núñez Jiménez de la Naturaleza y el Hombre.

Kløvstad, Kari. 1993. "Venta litt: Slik lærte Long Litt Woon å gå på tur." Oslo: Fjell og Vidde 6/93, 48-49.

König, Oliver. 1999. "Die Nacktheit beim Baden.” In Grisko 1999.

Krakauer, Jon. 1996. Into the Wild. London: Macmillan.

Naess, Arne. 1994. "The Norwegian Roots of Deep Ecology.” In Dahle 1994.

Nansen, Fridtjof. 1994. "Friluftsliv." In Dahle 1994.

Schneider, Uwe. 1999. "Nacktkultur im Kaiserreich.” In Grisko 1999.

Sutcliffe, William. 1997. Are You Experienced?. London: Penguin Books.

Ulbricht, Justus H. 1999. "Lichtgebet und Leibvergottung. Annäherungen an die Religiosität der Freikörperkultur”. In Grisko 1999.

Urry, John. 2002. The Tourist Gaze. London: Sage Publications.

Witoszek, Nina. 1998. Norske Naturmytologier: Fra Edda til Økofilosofi. Oslo: Pax Forlag.

Zapffe, Peter Wessel. 1993. Barske Glader. Oslo: Aventura. 